\title{
Kinetic Modeling of the Alkaline Decomposition of Potassium Arsenojarosite
}

\author{
Mizraim U. Flores, Francisco Patiño, * Iván A. Reyes, Isauro Rivera, \\ Martín Reyes and Julio C. Juárez.
}

\author{
Centro de Investigaciones en Materiales y Metalurgia, Universidad Autónoma del Estado de Hidalgo, \\ Carretera Pachuca, Tulancingo km 4.5, CP 42184, Mineral de la Reforma, Hidalgo, México
}

\begin{abstract}
Uma amostra de arsenojarosita de potássio foi sintetizada e completamente caracterizada. A amostra obtida é uma solução sólida de arsenojarosita de potássio, cuja fórmula aproximada é $\left[\mathrm{K}_{0,75}\left(\mathrm{H}_{3} \mathrm{O}\right)_{0,25}\right] \mathrm{Fe}_{1,84}\left[\left(\mathrm{SO}_{4}\right)_{1,82}\left(\mathrm{AsO}_{4}\right)_{0,18}\right]\left[(\mathrm{OH})_{2,34}\left(\mathrm{H}_{2} \mathrm{O}\right)_{3,66}\right]$. O processo de decomposição em meio alcalino foi estudado no período de indução e de conversão progressiva, e a ordem de reação e a energia de ativação foram determinadas para cada caso. Nas condições experimentais utilizadas, os resultados são consistentes com modelo de partícula esférica com núcleo decrescente e controle químico. Em ambos os processos, quatro modelos parciais e dois modelos globais foram desenvolvidos para descrever seu comportamento básico. Os modelos foram validados, e foi provado que descrevem favoravelmente o processo de decomposição em meio alcalino.
\end{abstract}

A sample of potassium arsenojarosite was synthesized and thoroughly characterized. The obtained sample is a solid solution of potassium arsenojarosite, whose approximate formula is $\left[\mathrm{K}_{0.75}\left(\mathrm{H}_{3} \mathrm{O}\right)_{0.25}\right] \mathrm{Fe}_{1.84}\left[\left(\mathrm{SO}_{4}\right)_{1.82}\left(\mathrm{AsO}_{4}\right)_{0.18}\right]\left[(\mathrm{OH})_{2.34}\left(\mathrm{H}_{2} \mathrm{O}\right)_{3.66}\right]$. The decomposition process in alkaline medium was studied in the induction and progressive conversion periods, and the reaction order and activation energy were determined for each case. Under the used experimental conditions, results are consistent with the spherical particle model with decreasing core and chemical control. In both processes, four partial models and two global models were developed in order to describe their basic behavior. The models were validated, and it was proved that they favorably describe the decomposition process in alkaline medium.

Keywords: potassium arsenojarosite, alkaline decomposition, kinetic modeling, activation energy, reaction order

\section{Introduction}

In many parts of the world, potable water is polluted with arsenic. This element is disposed of by mining and chemical industries, refineries, etc. ${ }^{1}$ The presence of arsenic in ground waters can be also natural because of the leaching of rocks and sediments that contain this element. ${ }^{2}$ These ground waters contain great amounts of arsenic, and they are consumed by millions of people around the world, in countries like Bangladesh, Cambodia, China, India, Laos, Myanmar, Nepal, Pakistan and Vietnam in Asia. ${ }^{3}$ This problem is also present in the American continent, in countries such as Argentina, Mexico, Chile, Peru, United States, Brazil and Canada. ${ }^{4,5}$ For these reasons, the U. S. Environmental Protection Agency has set the amount of $10 \mu \mathrm{g} \mathrm{L}{ }^{-1}$ as the maximum level of pollution allowed

*e-mail: uri_fg@hotmail.com in potable water. ${ }^{6}$ Thus, several alternatives have been studied in order to solve this problem. ${ }^{7}$ Jarosite technology has been applied for 40 years in the zinc industry as a way to control $\mathrm{Fe}$ and other impurities, such as As. Therefore, arsenic can be incorporated into the structure of the jarosites, which work as an inerting medium for this toxic element. Regarding this, Dutrizac et al. ${ }^{8,9}$ studied the incorporation of arsenic as $\mathrm{AsO}_{4}{ }^{3-}$ in the lattice of potassium, sodium and lead jarosite at 97 and $150{ }^{\circ} \mathrm{C}$. Patiño et al..$^{10-14}$ have thoroughly studied the alkaline reactivity of argentian jarosites in alkaline medium. Although there are several studies related to the alkaline decomposition of jarosite type compounds, only few ones are related to jarosite type compounds with arsenic. ${ }^{15,16}$ These works are focused on the characterization of the dissolution residues and on the kinetic study of these compounds. However, regarding the latter ${ }^{16}$ the obtained kinetic models were not verified. 
For this reason, in this research work, a kinetic study, which allows to describe and to predict the behavior of this compound, was carried out at different experimental conditions. Reaction rates and dependencies were compared in a wide range of experimental conditions of concentration, temperature and particle size. Partial and global kinetic models of the induction and progressive conversion periods were developed for the alkaline decomposition of the potassium arsenojarosite in $\mathrm{NaOH}$ and $\mathrm{Ca}(\mathrm{OH})_{2}$ media.

\section{Experimental}

The potassium arsenojarosite samples were synthesized using the parameters previously described by Dutrizac et al..$^{8,9}$ and characterized by different techniques.

The alkaline decomposition experiments in $\mathrm{NaOH}$ and $\mathrm{Ca}(\mathrm{OH})_{2}$ media were carried out under the following conditions: $0.2 \mathrm{~g}$ potassium arsenojarosite $(38 \pm 2 \mu \mathrm{m})$ in an initial volume of $0.5 \mathrm{~L}$, stirring rate of $500 \mathrm{~min}^{-1}$, varying the concentration of $\mathrm{OH}^{-}$, temperature and particle size. The $\mathrm{pH}$ value was kept constant during all the experiment in both media by adding small amounts of concentrated $\mathrm{NaOH}$ and $\mathrm{Ca}(\mathrm{OH})_{2}$, respectively. The $\mathrm{OH}^{-}$concentration was determined by considering the ionization constant of water and $\mathrm{pH}$ of the alkaline solution according to the temperatures used in a previous work. ${ }^{17}$

Figure 1 shows a scanning electron microscopy (SEM) image (JEOL JSM-5900 LV) of almost spherical particles, which are formed by soundly soldered rhombohedral crystals.

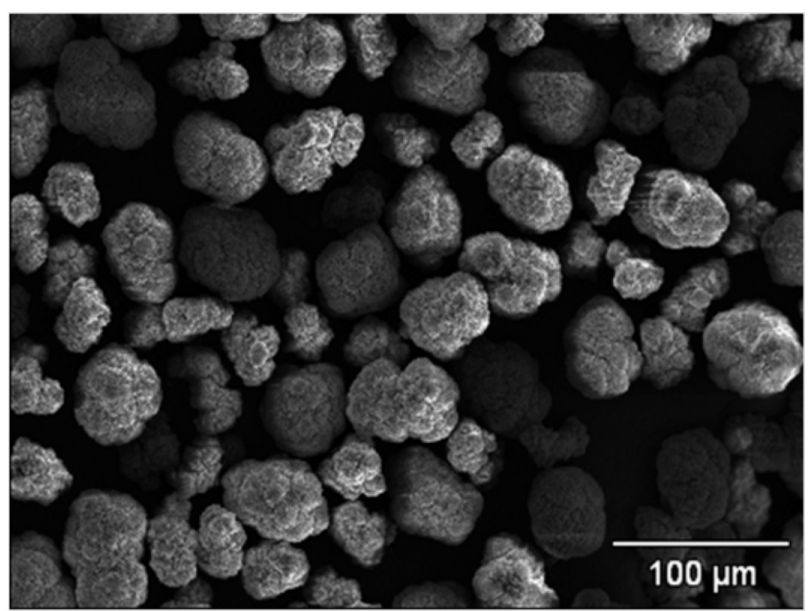

Figure 1. Particle size distribution of the synthesized potassium arsenojarosite.

The alkaline decomposition kinetics was monitored by atomic absorption spectroscopy (AAS) of potassium using a Perkin Elmer Analyst 200 equipment. For all of the performed experiments, the induction period $\left(\mathrm{t}_{\text {ind }}\right)$ was determined and the experimental rate constant $\left(\mathrm{k}_{\text {exp }}\right)$ was calculated. The kinetic modeling was carried out with the experimental results of the alkaline decomposition of potassium arsenojarosite. The solids at different decomposition times, as well as those submitted to high temperatures, were analyzed by X-ray diffractometry (SIEMENS D-500), SEM with an accelerating voltage of $20 \mathrm{kV}$ and microanalysis by energy-dispersive X-ray spectroscopy (SEM-EDS in an Oxford Equipment). The objective was to determine their evolving process. Tables 1 and 2 summarize the experimental data that were used in the modeling.

Table 1. Decomposition of potassium arsenojarosite in $\mathrm{NaOH}$ medium: $\mathrm{n}=2.65, \mathrm{E}_{\mathrm{a}}=84.7 \mathrm{~kJ} \mathrm{~mol}^{-1}$ for the induction period; $\mathrm{n}=1.86$, $\mathrm{E}_{\mathrm{a}}=60.3 \mathrm{~kJ} \mathrm{~mol}^{-1}$ for the progressive conversion period

\begin{tabular}{lccccc}
\hline $\mathrm{pH}$ & $\begin{array}{c}{\left[\mathrm{OH}^{-}\right] /} \\
\left(\mathrm{mol} \mathrm{L}^{-1}\right)\end{array}$ & $\mathrm{T} /{ }^{\circ} \mathrm{C}$ & $\mathrm{d}_{0} / \mu \mathrm{m}$ & $\begin{array}{c}\text { Induction } \\
\text { time, } \\
\mathrm{t}_{\text {ind }} / \mathrm{min}\end{array}$ & $\begin{array}{c}\mathrm{k}_{\text {exp }} / \\
\mathrm{min}^{-1}\end{array}$ \\
\hline 12.87 & 0.1081 & 30 & 38 & 0.04 & 0.088 \\
12.53 & 0.0494 & 30 & 38 & 0.61 & 0.031 \\
12.08 & 0.0175 & 30 & 38 & 5.00 & 0.004 \\
11.96 & 0.0133 & 30 & 38 & 13.00 & 0.003 \\
11.64 & 0.0064 & 30 & 38 & 87.72 & 0.001 \\
10.93 & 0.0012 & 30 & 38 & 144.88 & 0.001 \\
9.94 & 0.0001 & 30 & 38 & 217.86 & 0.001 \\
12.92 & 0.0571 & 20 & 38 & 4.46 & 0.022 \\
12.71 & 0.0519 & 25 & 38 & 3.00 & 0.026 \\
12.46 & 0.0596 & 35 & 38 & 0.68 & 0.072 \\
12.31 & 0.0586 & 40 & 38 & 0.57 & 0.112 \\
12.16 & 0.0569 & 45 & 38 & 0.27 & 0.166 \\
12.08 & 0.0638 & 50 & 38 & 0.17 & 0.278 \\
11.90 & 0.0560 & 55 & 38 & - & 0.289 \\
11.79 & 0.0570 & 60 & 38 & - & 0.369 \\
12.77 & 0.0859 & 30 & 75 & 1.56 & 0.0133 \\
12.80 & 0.0920 & 30 & 53 & 0.18 & 0.0189 \\
12.78 & 0.0879 & 30 & 45 & 0.65 & 0.0222 \\
12.83 & 0.0986 & 30 & 25 & 0.49 & 0.0400 \\
12.81 & 0.0942 & 30 & 23 & 0.34 & 0.0435 \\
\hline & & & & &
\end{tabular}

\section{Results and Discussion}

Topology of the reaction

The decomposition of potassium arsenojarosite in $\mathrm{NaOH}$ and $\mathrm{Ca}(\mathrm{OH})_{2}$ media presents an induction period $\left(\mathrm{t}_{\text {ind }}\right)$, during which the arsenojarosite does not react. Therefore, the $\mathrm{SO}_{4}{ }^{2-}$ and $\mathrm{K}^{+}$concentrations are found at negligible levels in the solution (Figure 2). The induction period has been observed in the decomposition of jarosites synthesized in the laboratory, as well as in those coming from industrial plants. ${ }^{18}$ The ion concatenation of the medium with the surface of the particle creates active sites until a reaction front is established, and through which the 
Table 2. Decomposition of potassium arsenojarosite in $\mathrm{Ca}(\mathrm{OH})_{2}$ medium: $\mathrm{n}=0.24, \mathrm{E}_{\mathrm{a}}=88.3 \mathrm{~kJ} \mathrm{~mol}^{-1}$ for the induction period; $\mathrm{n}=1.14$, $\mathrm{E}_{\mathrm{a}}=74.4 \mathrm{~kJ} \mathrm{~mol}^{-1}$ for the progressive conversion period

\begin{tabular}{lccccc}
\hline $\mathrm{pH}$ & $\begin{array}{c}{\left[\mathrm{OH}^{-}\right] /} \\
\left(\mathrm{mol} \mathrm{L}^{-1}\right)\end{array}$ & $\mathrm{T} /{ }^{\circ} \mathrm{C}$ & $\mathrm{d}_{0} / \mu \mathrm{m}$ & $\begin{array}{c}\text { Induction } \\
\text { time, } \mathrm{t}_{\text {ind }} / \\
\text { min }\end{array}$ & $\begin{array}{c}\mathrm{k}_{\text {exp }} / \\
\text { min }^{-1}\end{array}$ \\
\hline 12.53 & 0.0494 & 30 & 38 & 28.5 & 0.006 \\
12.48 & 0.0441 & 30 & 38 & 28.6 & 0.005 \\
12.43 & 0.0393 & 30 & 38 & 28.6 & 0.004 \\
12.33 & 0.0312 & 30 & 38 & 29.3 & 0.003 \\
12.12 & 0.0192 & 30 & 38 & 33.2 & 0.002 \\
11.87 & 0.0108 & 30 & 38 & 41.0 & 0.002 \\
11.25 & 0.0026 & 30 & 38 & 56.0 & 0.002 \\
11.06 & 0.0017 & 30 & 38 & 65.0 & 0.002 \\
12.8 & 0.0434 & 20 & 38 & 52.0 & 0.002 \\
12.55 & 0.0359 & 25 & 38 & 39.5 & 0.003 \\
12.03 & 0.0221 & 35 & 38 & 22.0 & 0.003 \\
11.95 & 0.0256 & 40 & 38 & 19.6 & 0.008 \\
11.74 & 0.0216 & 45 & 38 & 16.6 & 0.009 \\
11.58 & 0.0202 & 50 & 38 & 11.7 & 0.013 \\
11.44 & 0.0194 & 55 & 38 & 9.2 & 0.018 \\
11.24 & 0.0161 & 60 & 38 & 3.5 & 0.020 \\
11.12 & 0.0158 & 65 & 38 & 0.9 & 0.041 \\
10.93 & 0.0131 & 70 & 38 & - & 0.043 \\
12.24 & 0.0254 & 30 & 75 & 40.0 & 0.0010 \\
12.22 & 0.0242 & 30 & 53 & 31.5 & 0.0020 \\
12.27 & 0.0272 & 30 & 45 & 29.7 & 0.0026 \\
12.29 & 0.0284 & 30 & 28 & 23.2 & 0.0039 \\
12.25 & 0.0259 & 30 & 23 & 17.3 & 0.0047 \\
\hline & & & & &
\end{tabular}

ions of the medium and the potassium arsenojarosite start to diffuse. This is followed by a progressive conversion period, when the concentrations of $\mathrm{SO}_{4}{ }^{2-}$ and $\mathrm{K}^{+}$progressively increase until reaching stabilization (Figure 2), indicating the end of the reaction.

Figure 3a is an SEM image of a partially decomposed potassium arsenojarosite particle, showing an unreacted core surrounded by a reaction front, which is wrapped in an amorphous gel of iron hydroxide with arsenic. This can be confirmed in Figure 3b, which shows a linescan (indicated in Figure 3a) of the partially decomposed particle, from the core to the halo of the amorphous gel. This figure shows how the amount of sulfur and potassium decreased, indicating that these species have diffused from the core to the solution, while iron and arsenic are still distributed throughout the particle. The relative amounts of all the species are constant in the core, which means that it did not react. The residues do not evolve into new crystal phases, not even after reaching total decomposition (0-10 h). This was evidenced by the X-ray diffractograms in Figure 4 , in which the decomposition product is observed

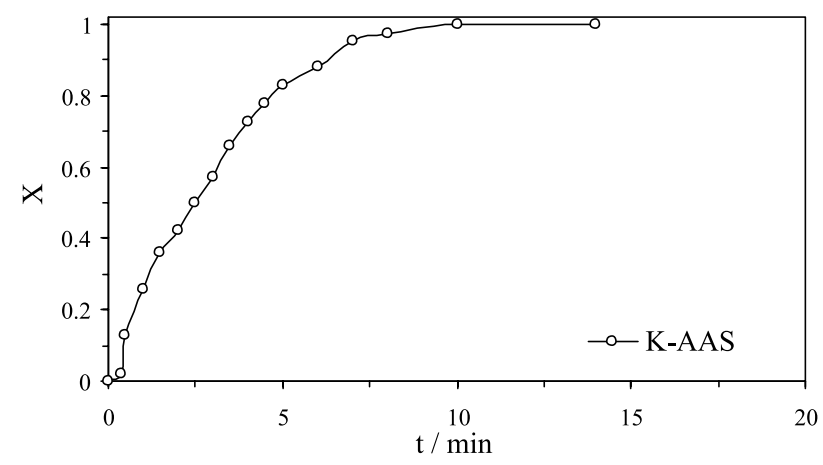

Figure 2. Alkaline decomposition curve of the potassium arsenojarosite, $\mathrm{pH} 12.78,38 \pm 2 \mu \mathrm{m}, 30^{\circ} \mathrm{C}$.
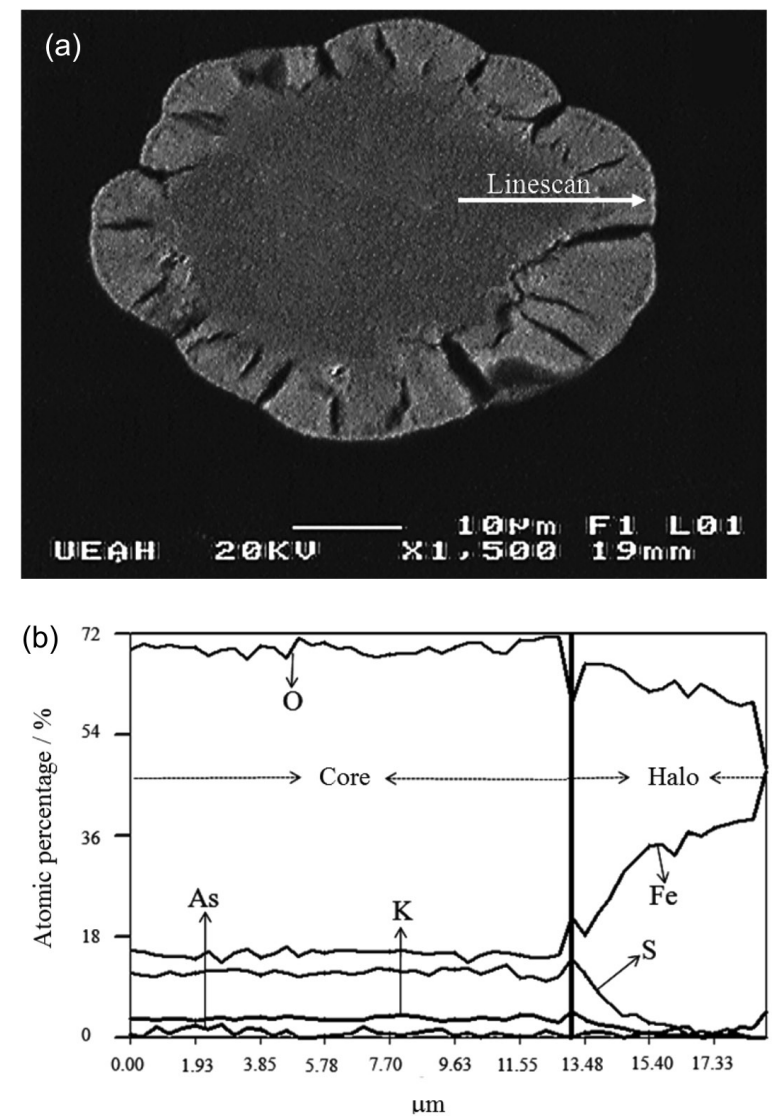

Figure 3. (a) Potassium arsenojarosite particle partially decomposed in $\mathrm{NaOH}$ medium, $\mathrm{pH} 12.78,38 \pm 2 \mu \mathrm{m}, 30^{\circ} \mathrm{C}$ and (b) linescan of the particle shown in figure $3 \mathrm{~A}$.

as an amorphous material. Therefore, the process is given by the following reaction:

$$
\begin{aligned}
& {\left[\mathrm{K}_{0.75}\left(\mathrm{H}_{3} \mathrm{O}\right)_{0.25}\right] \mathrm{Fe}_{1.84}\left[\left(\mathrm{SO}_{4}\right)_{1.82}\left(\mathrm{AsO}_{4}\right)_{0.18}\right]\left[(\mathrm{OH})_{2.34}\left(\mathrm{H}_{2} \mathrm{O}\right)_{3.66}\right]} \\
& +3.43 \mathrm{OH}^{-}{ }_{(\mathrm{aq})} \rightarrow 0.75 \mathrm{~K}^{+}{ }_{(\mathrm{aq})}+1.82 \mathrm{SO}_{4}{ }^{2-}{ }_{(\mathrm{aq})}+ \\
& 1.84 \mathrm{Fe}(\mathrm{OH})_{3} 0.18 \mathrm{AsO}_{4}{ }^{3-}{ }_{(\mathrm{gel})}+4.16 \mathrm{H}_{2} \mathrm{O}
\end{aligned}
$$

The decomposition solids were exposed to high temperatures. At 110 and $400{ }^{\circ} \mathrm{C}$, there is no formation of new crystal phases, but sharp diffraction peaks, 


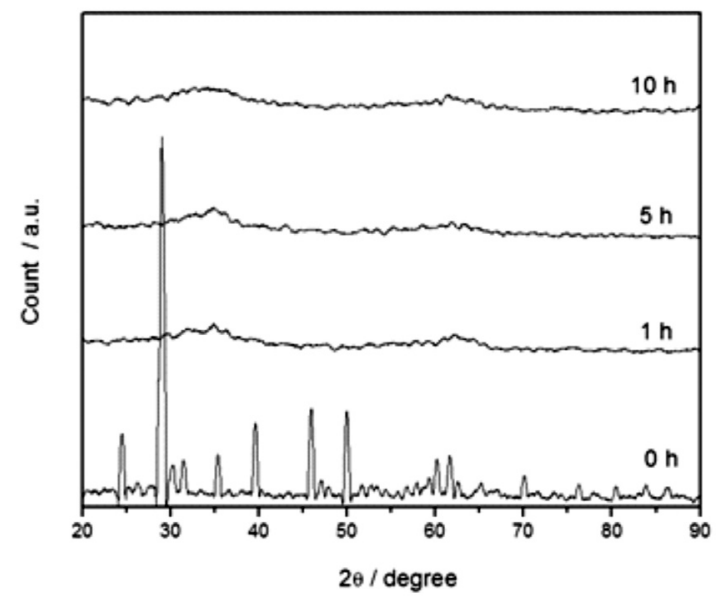

Figure 4. X-ray diffractograms of a potassium arsenojarosite sample at different decomposition times in $\mathrm{NaOH}: \mathrm{pH} 12.78,38 \pm 2 \mu \mathrm{m}, 30^{\circ} \mathrm{C}$.

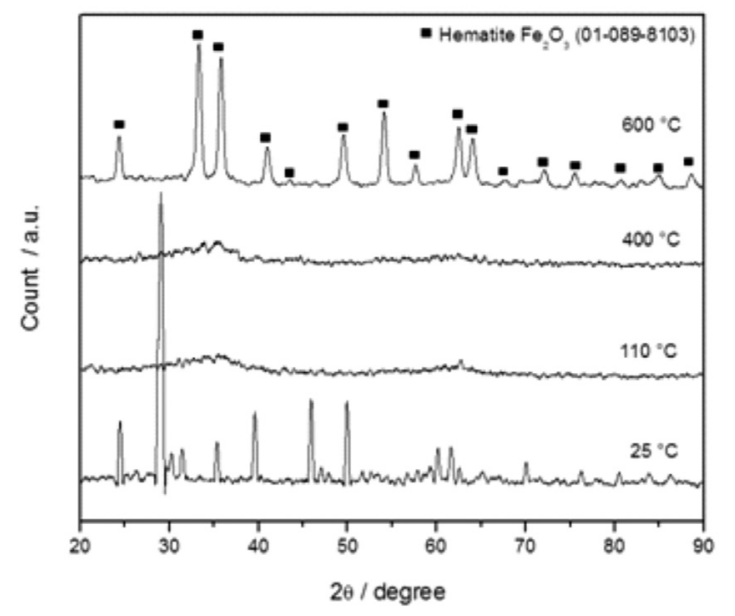

Figure 5. X-ray diffractograms of the total decomposition product heated at 110,400 and $600{ }^{\circ} \mathrm{C}$ for $1 \mathrm{~h}$, including the identification of the phase formed at $600{ }^{\circ} \mathrm{C}$.

characteristic of crystalline hematite, $\mathrm{Fe}_{2} \mathrm{O}_{3}$ (01-089-8103), were observed after thermal treatment at $600{ }^{\circ} \mathrm{C}$ (Figure 5). ${ }^{13}$

All results in $\mathrm{NaOH}$ and $\mathrm{Ca}(\mathrm{OH})_{2}$ media, it can be explained using the spherical particle model with decreasing core, in which the process is controlled by the chemical reaction according to the following expressions: ${ }^{19-21}$

$\mathrm{k}_{\exp } \mathrm{t}=1-(1-\mathrm{X})^{1 / 3}$

where

$\mathrm{k}_{\mathrm{exp}}=\frac{\mathrm{V}_{\mathrm{M}_{\mathrm{q}} \mathrm{k}_{\mathrm{A}} \mathrm{c}^{\mathrm{n}}}}{\mathrm{r}_{0}}$

$\mathrm{k}_{\text {exp }}$ is the experimental rate constant, $\mathrm{X}$ is the fraction that reacted, $\mathrm{V}_{\mathrm{M}}$ is the molar volume of the solid, $\mathrm{c}_{\mathrm{A}}$ represents the reactant concentration, $\mathrm{r}_{0}$ stands for the initial radius of the particle, $\mathrm{k}_{\mathrm{q}}$ is the rate constant of the chemical reaction and $\mathrm{n}$ is the reaction order. Figure 6 presents the experimental results from Figure 2 after applying equation 2 , and it can be observed that they are consistent with the chemical control expression as the stage that controls the reaction rate.

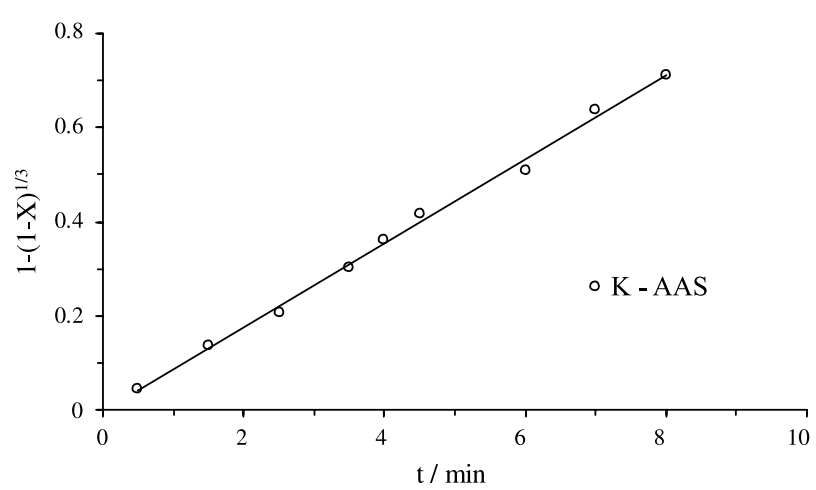

Figure 6. Representation of the decreasing core model with chemical control of the data in Figure 2.

Modeling

Arsenojarosite decomposition in alkaline medium

Tables 1 and 2 summarize the experimental results, in which the induction period $\left(\mathrm{t}_{\mathrm{ind}}\right)$ and experimental rate constant are presented within a wide range of experimental conditions, such as $\mathrm{NaOH}$ and $\mathrm{Ca}(\mathrm{OH})_{2}$ concentrations, temperature and particle size. The initial $\mathrm{pH}$ was kept constant along the reaction, and the $\left[\mathrm{OH}^{-}\right]$was calculated according to the ionic constant of water at the working temperature of each reaction, as previously mentioned in the Experimental section. ${ }^{17}$

Induction period $\left(\mathrm{t}_{\text {ind }}\right)$

For the induction period of the potassium arsenojarosite decomposition in $\mathrm{NaOH}$ medium with $\left[\mathrm{OH}^{-}\right]>6.4 \times 10^{-3} \mathrm{~mol} \mathrm{~L}^{-1}$, a fractional reaction order of $\mathrm{n}=2.65$ was obtained. The calculated activation energy in $\mathrm{NaOH}$ medium is $\mathrm{E}_{\mathrm{a}}=84.7 \mathrm{~kJ} \mathrm{~mol}^{-1}$. In the case of the $\mathrm{Ca}(\mathrm{OH})_{2}$ with $\left[\mathrm{OH}^{-}\right]>3.1 \times 10^{-2} \mathrm{~mol} \mathrm{~L}^{-1}$, the fractional reaction order is $n=0.24$. The calculated activation energy in $\mathrm{Ca}(\mathrm{OH})_{2}$ medium is $\mathrm{E}_{\mathrm{a}}=88.3 \mathrm{~kJ} \mathrm{~mol}^{-1}$. According to these results, the induction period for $\mathrm{NaOH}$ is defined by the following expressions.

$$
\begin{gathered}
\text { For }\left[\mathrm{OH}^{-}\right]>6.4 \times 10^{-3} \mathrm{~mol} \mathrm{~L}^{-1}: \\
1 / \theta=\frac{1}{\left(\mathrm{r}_{0} \mathrm{v}_{\mathrm{M}}\right)}\left[\mathrm{OH}^{-}\right]^{2.65} 5.6 \times 10^{17} \mathrm{e}^{-84700 / R T}
\end{gathered}
$$

For the induction period in $\mathrm{Ca}(\mathrm{OH})_{2}$ medium with $[\mathrm{OH}]>3.1 \times 10^{-2} \mathrm{~mol} \mathrm{~L}^{-1}$, the expression is the following:

$1 / \theta=\frac{1}{\left(\mathrm{r}_{0} \mathrm{v}_{\mathrm{M}}\right)}\left[\mathrm{OH}^{-}\right]^{0.24} 3.4 \times 10^{13} \mathrm{e}^{-88300 / \mathrm{RT}}$ 


\section{Progressive conversion period}

For the progressive conversion period corresponding to the potassium arsenojarosite decomposition in $\mathrm{NaOH}$ medium with $\left[\mathrm{OH}^{-}\right]>6.4 \times 10^{-3} \mathrm{~mol} \mathrm{~L}^{-1}$, a fractional reaction order of $n=1.86$ was obtained. The activation energy calculated in $\mathrm{NaOH}$ medium is $\mathrm{E}_{\mathrm{a}}=60.3 \mathrm{~kJ} \mathrm{~mol}^{-1}$. Therefore, the kinetic expression for the progressive conversion period in $\mathrm{NaOH}$ medium is as follows.

$$
\begin{gathered}
\text { For }\left[\mathrm{OH}^{-}\right]>6.4 \times 10^{-3} \mathrm{~mol} \mathrm{~L}^{-1}: \\
1-(1-\mathrm{X})^{1 / 3}=2.37 \times 10^{11} \mathrm{e}^{-60300 / \mathrm{RT}}\left[\mathrm{OH}^{-}\right]^{1.86} \mathrm{t}
\end{gathered}
$$

For the progressive conversion period corresponding to the potassium arsenojarosite decomposition in $\mathrm{Ca}(\mathrm{OH})_{2}$ with $\left[\mathrm{OH}^{-}\right]>1.92 \times 10^{-2} \mathrm{~mol} \mathrm{~L}{ }^{-1}$, a fractional reaction order of $n=1.14$ was obtained. The activation energy calculated in $\mathrm{Ca}(\mathrm{OH})_{2}$ medium is $\mathrm{E}_{\mathrm{a}}=74.4 \mathrm{~kJ} \mathrm{~mol}^{-1}$, so the kinetic expression for the progressive conversion period in $\mathrm{Ca}(\mathrm{OH})_{2}$ is as follows.

$$
\begin{gathered}
\text { For }\left[\mathrm{OH}^{-}\right]>1.92 \times 10^{-2} \mathrm{~mol} \mathrm{~L}^{-1}: \\
1-(1-\mathrm{X})^{1 / 3}=1.2 \times 10^{12} \mathrm{e}^{-74400 / \mathrm{RT}^{-}}\left[\mathrm{OH}^{-}\right]^{1.14} \mathrm{t}
\end{gathered}
$$

Figure 7 is a plot of the development of the kinetic model according to equations 4 and 5, showing the experimental induction period $\left(\mathrm{t}_{\text {ind-exp }}(\mathrm{min})\right) v s$. the calculated induction period $\left(\mathrm{t}_{\text {ind-calc }}(\mathrm{min})\right)$. Since the induction and progressive conversion periods are at different magnitude orders, the base 10 logarithms of the calculated and experimental induction periods were plotted.

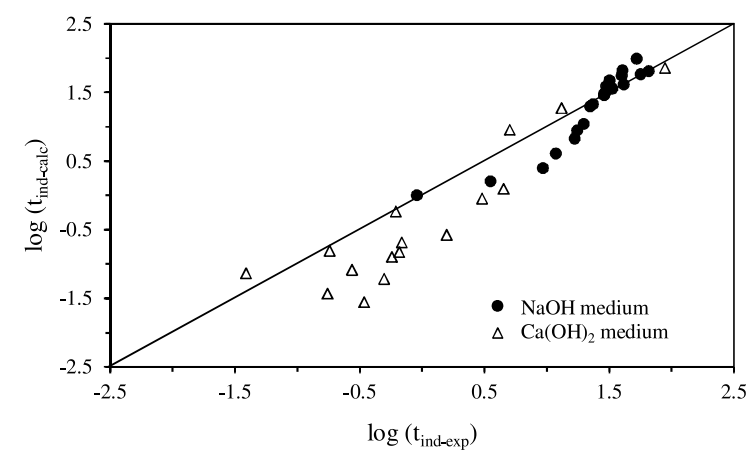

Figure 7. Induction period. Alkaline decomposition of the potassium arsenojarosite. Comparison between the calculated and experimental data in $\mathrm{NaOH}$ and $\mathrm{Ca}(\mathrm{OH})_{2}$ media.

Figure 8 presents the development of equation 6 , being a plot of the experimental rate constant vs. the calculated rate constant, e.g., $\mathrm{k}_{\text {exp }}\left(\mathrm{min}^{-1}\right)$ vs. $\mathrm{k}_{\text {calc }}\left(\mathrm{min}^{-1}\right)$ in $\mathrm{NaOH}$ medium. Likewise, Figure 9 depicts the development of equation 7, which represents the behavior of the progressive conversion period in $\mathrm{Ca}(\mathrm{OH})_{2}$ medium.

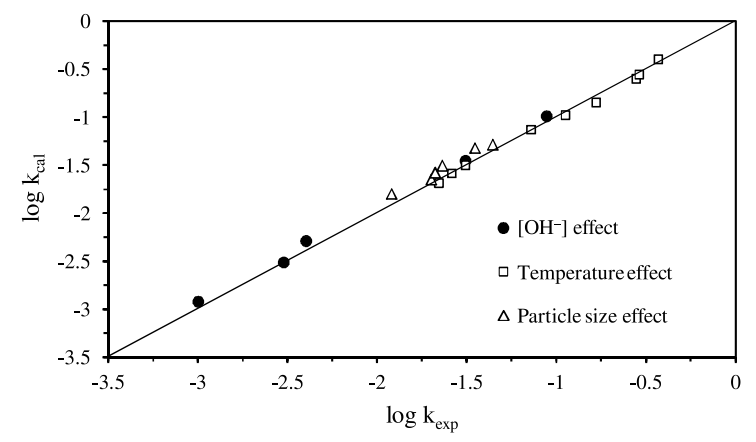

Figure 8. Progressive conversion period. Alkaline decomposition of the potassium arsenojarosite in $\mathrm{NaOH}$ medium. Comparison between the calculated and experimental data, $\left[\mathrm{OH}^{-}\right]>6.4 \times 10^{-3} \mathrm{~mol} \mathrm{~L}^{-1}$.

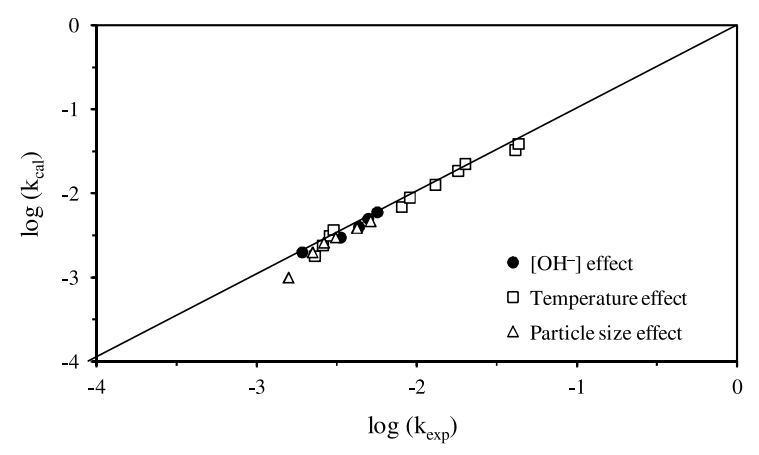

Figure 9. Progressive conversion period. Alkaline decomposition of the potassium arsenojarosite in $\mathrm{Ca}(\mathrm{OH})_{2}$ medium. Comparison between the calculated and experimental data, $\left[\mathrm{OH}^{-}\right]>1.92 \times 10^{-2} \mathrm{~mol} \mathrm{~L}^{-1}$.

In all the kinetic expressions: $\mathrm{v}_{\mathrm{M}}=153.07 \mathrm{~cm}^{3} \mathrm{~mol}^{-1}$, $\mathrm{R}=8.3144 \mathrm{~J} \mathrm{~mol}^{-1} \mathrm{~K}^{-1}, \mathrm{r}_{0}$ in $\mathrm{cm}, \mathrm{T}$ in Kelvin, $\left[\mathrm{OH}^{-}\right]$in $\mathrm{mol} \mathrm{L}-1$ and $\mathrm{t}$ in minutes.

From equations 4 and 6 , corresponding to the alkaline decomposition in $\mathrm{NaOH}$ medium with $\left[\mathrm{OH}^{-}\right]>6.4 \times 10^{-3} \mathrm{~mol} \mathrm{~L}-1$, a general expression can be established in order to determine the total reaction time needed for obtaining a definite conversion of the potassium arsenojarosite. The kinetic model is the following:

$$
\mathrm{t}_{\mathrm{X}}=\frac{1}{\left(\frac{1}{\mathrm{r}_{0} \mathrm{v}_{\mathrm{M}}}\right)\left[\mathrm{OH}^{-}\right]^{2.65} 5.6 \times 10^{17} \mathrm{e}^{-84700 / R \mathrm{~T}}}+\frac{1-(1-\mathrm{X})^{1 / 3}}{2.37 \times 10^{11} \mathrm{e}^{-60300 / R T}\left[\mathrm{OH}^{-}\right]^{1.86}}
$$

Figure 10 shows the total reaction time needed for obtaining a potassium arsenojarosite conversion of $\mathrm{X}=0.75$ (calculated according to equation 8) vs. the same experimentally obtained parameters. It can be concluded that equation 8 is consistent with the experimental results because the experimental and the calculated data do not show any considerable differences.

For equations 5 and 7 , corresponding to the decomposition in $\mathrm{Ca}(\mathrm{OH})_{2}$ medium, an expression was 


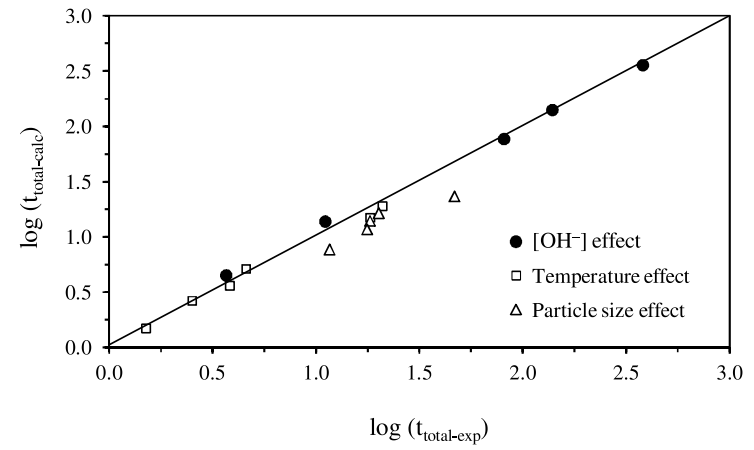

Figure 10. Alkaline decomposition in $\mathrm{NaOH}$ medium. Plot of the reaction total time obtained at an $\mathrm{X}=0.75$ conversion (experimental $v s$. calculated).

established in order to determine the total reaction time needed for obtaining a definite conversion of the potassium arsenojarosite. The kinetic model is the following:

$\mathrm{t}_{\mathrm{X}}=\frac{1}{\left(\frac{1}{\mathrm{r}_{0} \mathrm{~V}_{\mathrm{M}}}\right)\left[\mathrm{OH}^{-}\right]^{0.24} 3.4 \times 10^{13} \mathrm{e}^{-88300 / R T}}+\frac{1-(1-\mathrm{X})^{1 / 3}}{1.2 \times 10^{12} \mathrm{e}^{-74400 / \mathrm{RT}^{2}}\left[\mathrm{OH}^{-}\right]^{1.14}}$

Figure 11 shows the total reaction time needed for obtaining a conversion of $\mathrm{X}=0.75$ (calculated according to equation 9) $v s$. the same parameter (experimentally obtained). It can be concluded, therefore, that equation 9 is consistent with the experimental results of the decomposition in $\mathrm{Ca}(\mathrm{OH})_{2}$ medium.

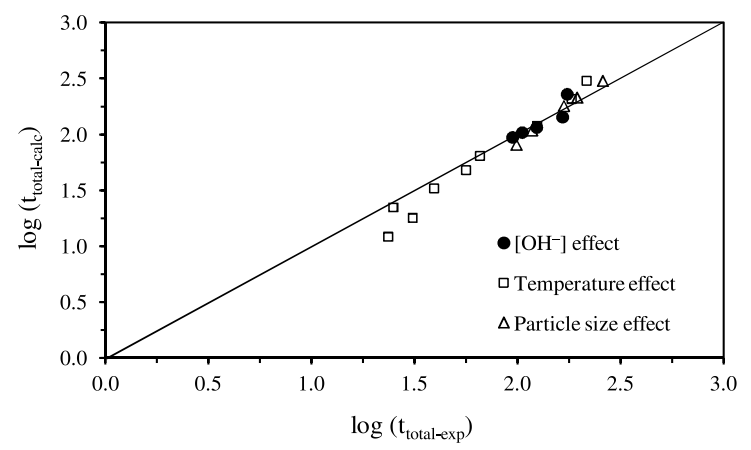

Figure 11. Alkaline decomposition in $\mathrm{Ca}(\mathrm{OH})_{2}$ medium. Plot of the reaction total time obtained at an $\mathrm{X}=0.75$ conversion (experimental $v s$. calculated).

\section{Conclusions}

The decomposition solids do not evolve into new crystal phases after reaching total decomposition. However, after being heated at $600{ }^{\circ} \mathrm{C}$, the decomposition product evolves into a new crystal phase, which was identified as hematite $\left(\mathrm{Fe}_{2} \mathrm{O}_{3}\right)$. The general mathematical models for the decomposition of potassium arsenojarosite in $\mathrm{NaOH}$ and $\mathrm{Ca}(\mathrm{OH})_{2}$ media during the induction and progressive conversion periods are presented as follows:

$\mathrm{t}_{\mathrm{X}}=\frac{1}{\left(\frac{1}{\mathrm{r}_{\mathrm{O}} \mathrm{V}_{\mathrm{M}}}\right)\left[\mathrm{OH}^{-}\right]^{2.65} 5.6 \times 10^{17} \mathrm{e}^{-84700 / \mathrm{RT}}}+\frac{1-(1-\mathrm{X})^{1 / 3}}{2.37 \times 10^{11} \mathrm{e}^{-60300 / \mathrm{RT}^{T}}\left[\mathrm{OH}^{-}\right]^{1.86}} \quad \mathrm{NaOH}$
$\mathrm{t}_{\mathrm{X}}=\frac{1}{\left(\frac{1}{\mathrm{r}_{0} \mathrm{~V}_{\mathrm{M}}}\right)\left[\mathrm{OH}^{-}\right]^{0.24} 3.4 \times 10^{13} \mathrm{e}^{-88300 / R \mathrm{~T}}}+\frac{1-(1-\mathrm{X})^{1 / 3}}{1.2 \times 10^{12} \mathrm{e}^{-7440 / \mathrm{RT}^{2}}\left[\mathrm{OH}^{-}\right]^{1.14}} \mathrm{Ca}(\mathrm{OH})_{2}$

These models describe the process of alkaline decomposition of the potassium arsenojarosite. They will also allow to predict its behavior at different temperature $\left(20-60^{\circ} \mathrm{C}\right)$ and concentration conditions $\left(0.1-2.7 \times 10^{-4} \mathrm{~mol} \mathrm{~L}^{-1}\right.$ for $\mathrm{NaOH}$ and $2.3 \times 10^{-2}-7 \times 10^{-4} \mathrm{~mol} \mathrm{~L}^{-1}$ for $\left.\mathrm{Ca}(\mathrm{OH})_{2}\right)$.

\section{References}

1. Korngold, E.; Belayev, L. A.; Desalination 2001, 141, 81.

2. Thomas, S. Y.; Choong, T. G.; Chuah, Y. R.; Gregory K.; Azni, I.; Desalination 2007, 217, 139.

3. Brammer, H.; Environ. Int. 2009, 35, 856.

4. Mandal, B. K.; Suzuki, K. T.; Talanta 2002, 58, 201.

5. Ning, R. Y.; Desalination 2002, 143, 237.

6. EPA Office of groundwater and drinking water. Implementation guidance for the arsenic rule. EPA 2002, report-816-D-02-005-, Cincinnati, USA.

7. Katsoyiannis, I. A.; Zouboulis A. I.; Water Res. 2004, 38, 17.

8. Dutrizac, J. E.; Jambor, J. L.; Can. Metall. Q. 1987, 26, 91.

9. Dutrizac, J. E.; Jambor, J. L.; Chen, T. T.; Can. Metall. Q. 1987, 26, 103.

10. Patiño, F.; J. Mex. Chem. Soc. 1993, 37, 51.

11. Patiño, F.; Cruells, M.; Roca, A.; Salinas, E.; Perez, M.; Hydrometallurgy 2003, 70, 153.

12. Patiño, F.; Salinas, E.; Cruells, M.; Roca, A.; Hydrometallurgy 1998, 49, 323.

13. Patiño, F.; Roca, A.; Reyes, M.; Cruells, M.; Rivera, I.; Hernández, L. E.; J. Mex. Chem. Soc. 2010, 54, 216.

14. Patiño F.; Reyes, I.; Rivera, I.; Reyes, M.; Hernández, J.; Pérez, M.; J. Mex. Chem. Soc. 2011, 55, 197.

15. Smith, A. M. L.; Dubbin, W. E.; Wright, K.; Hudson-Edwards, K. A.; Chem. Geol. 2006, 229, 344.

16. Reyes, I. A.; Patiño, F.; Rivera I.; Flores, M. U.; Reyes, M.; Hernández, J.; J. Braz. Chem. Soc. 2011, 22, 2260.

17. Lide, D. R; Handbook of Chemistry and Physics, $89^{\text {th }}$ ed.; CRC Press: Boston, 2009, ch. 8.

18. Roca, A.; Cruells, M.; Patiño, F.; Rivera, I.; Plata, M.; Hydrometallurgy 2006, 81, 15.

19. Levenspiel, O.; Ingeniería de las Reacciones Químicas, $3^{\text {th }} \mathrm{ed}$; Reverte: Barcelona, 2010, ch. 25.

20. Ballester, A.; Verdeja, L. F.; Sancho, J.; Metalurgia Extractiva Fundamentos, vol. 1; Editorial Síntesis: Madrid, 2000, ch. 7.

21. Sohn, H. Y.; Wadsworth, M. E.; Cinética de los Procesos de la Metalurgia Extractiva; Trillas: México, 1986, ch. 1.

Submitted: December 15, 2011 Published online: April 26, 2012 